\title{
Detection of Potential Hazards at Different Phases of Fish and Prawn Processing Plants in Khulna
}

\author{
A. Nargis, ${ }^{a}$ M. A. Hossain and S. Parween ${ }^{b}$ \\ ${ }^{a}$ BCSIR Laboratories, Rajshahi and ${ }^{b}$ Department of Zoology, University of Rajshahi, \\ Rajshahi, Bangladesh
}

\begin{abstract}
Frozen fish and prawns occupy the highest rank among the export commodities. Export market of frozen fish/prawn totally depends on the freshness of the commodity. In order to give quality assurance of frozen fish and prawns of Bangladesh, the HACCP system is needed for different mechanisms of processing and consumption. In the present investigation, a total of 10 critical points were identified with farm to processing plants. The identification of potential hazards at different phases (catch and storage at fishing area, transportation, prior to processing, factory hygiene, processing, freezing, packaging, storage and shipment and storage at shipping area) of fish and prawn shrimp processing, and implementation of Hazard Analysis Critical Control Points (HACCP) system in this industry is the only weapon which can increase the demand of fish and prawns of Bangladesh in export market.
\end{abstract}

Key words: Potential hazards, critical control points, HACCP, Fish processing plants

\section{Introduction}

For quality assurance of frozen fishes and prawns of Bangladesh for export, the HACCP (Hazard Analysis Critical Control Points) system is very much needed, from the point of catch up to consumption, i.e., during the journey from farm to processing plants and storage via some middle-men or agents. Precaution should be taken at every phase of the processing of raw materials. Quality maintenance might reach at a level that satisfies the customer, and also is economical to the producer or seller (Connell, 1971). In the year 1997, EU (European Union) Commission imposed a temporary ban on prawns exported from Bangladesh for unhygienic condition of the product. However, after the introduction of HACCP system in 1998, the bacterial load of Bagda (Penaeus monodon) decreased more than three times than the previous year (Bhuiyan, 2004). 
The present work deals with the identification of potential hazards that occur at different phases of fish/prawn processing, and implementation of HACCP system in the fish processing industries of Khulna Division.

\section{Materials and Methods}

To investigate the hazards present in the system from farm to Processing Plants, the environment of the farm areas were studied along with the human facilities established around there. Occasional interviews were taken from the personnels engaged in Prawn Farming. The Fish/Prawn Farms under study period were situated at Kaligang, Parulia, Paikgachha, Rampal, Ashasoni and Shyamnagar of Khulna Division.

Physical investigation was made to observe the establishment of HACCP system in the fish Processing Plants, and different models of the system was prepared based on the information obtained from these Plants. A total of five (5) export based fish/prawn processing industries were visited where the HACCP system had been implemented. All the Plants were situated in Khulna.

\section{Results and Discussion}

In the present investigation a total of 10 critical points were identified from farm to Processing Plants (Fig. 1). The important points are discussed bellow:

A. Critical points at farm level: There is every possibility of contamination of the fish from the farm water and its environment.

i) Very often the gher (farm) is connected with rivers by feeding canals almost all the industries of Khulna drain their wastes into the rivers.

ii) Homestead wastes of daily life together with the faecal materials of the laborers working in the farm have direct passage to the farm ponds.

iii) The bay water is also polluted due to the throw out materials from the ship together with oil linkage.

So, the fry and rearing stocks of the farm are usually polluted. During the present investigation most of the farms of Satkhira were found to be affected by "China virus", resulting in higher mortality rate of the prawns. Along with polluted water of the farms the following hazardous points were also recorded from under survey.

i) Absence of regular monitoring in the farms for pollution from biotoxins.

ii) HACCP system prescribes for limited time of catching/fishing (maximum for three hours) and advises how to avoid rough handling, however, these are not maintained at all.

iii) Harvested fish are heaped in baskets without any ice and transported to the landing centre without protecting from sunlight. 


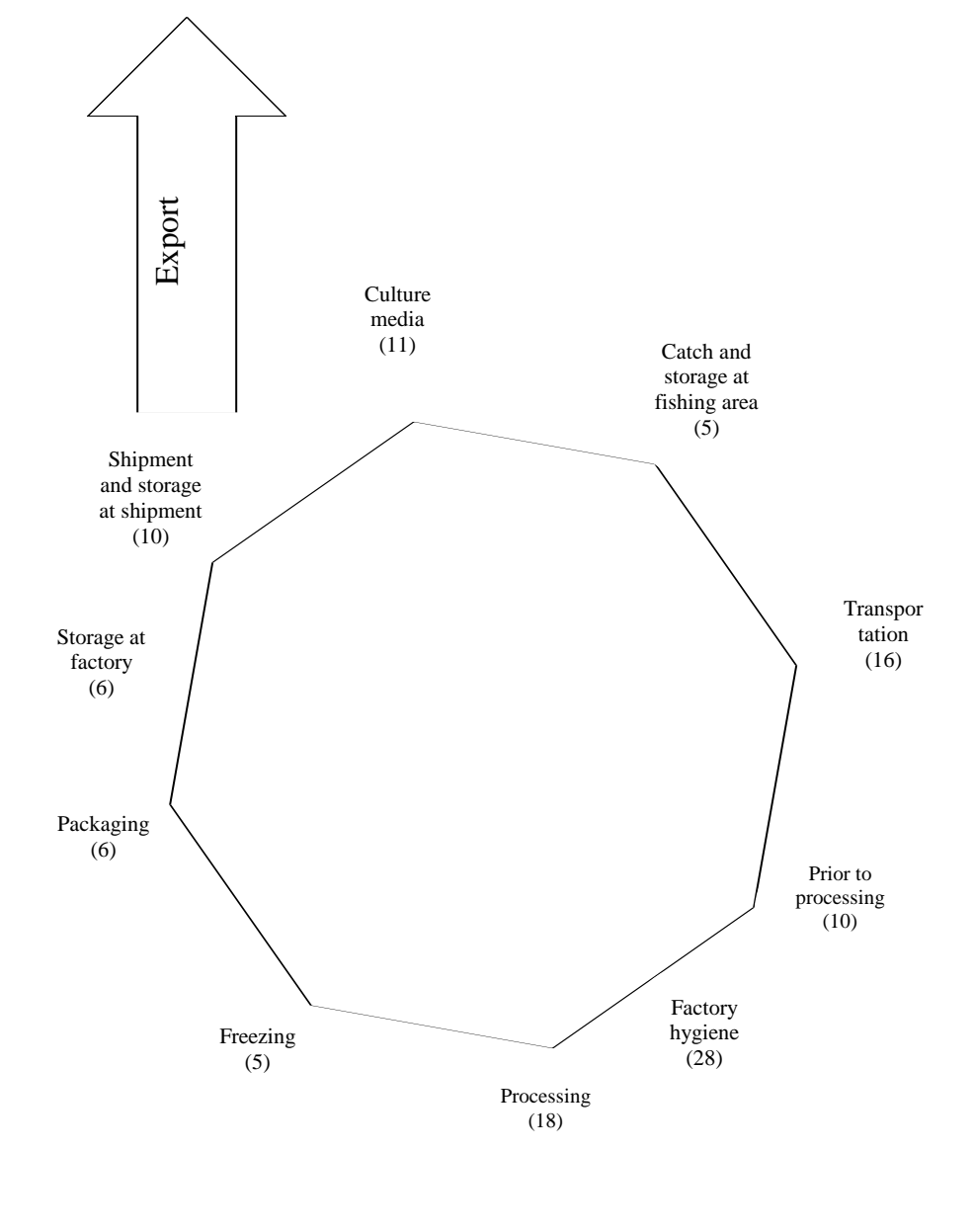

Fig.1. Potential hazards as identified at different phases of fish/prawn processing plants

iv) The carrying containers are not washed regularly and mostly are in filthy condition.

B. Critical points at landing centre: While transporting from farm to landing centers/depots, the fish are packed in bamboo baskets and wooden boxes with ice, cov ered with hogla or banana leaf. i) From landing centre when the commodities are transported to the Processing Plants, it takes sometimes 34 days, when they lose their freshness on the way.

ii) Most of the landing centres do not maintain hygienic condition at all. 


\section{POST-HARVEST FLOW CHART}

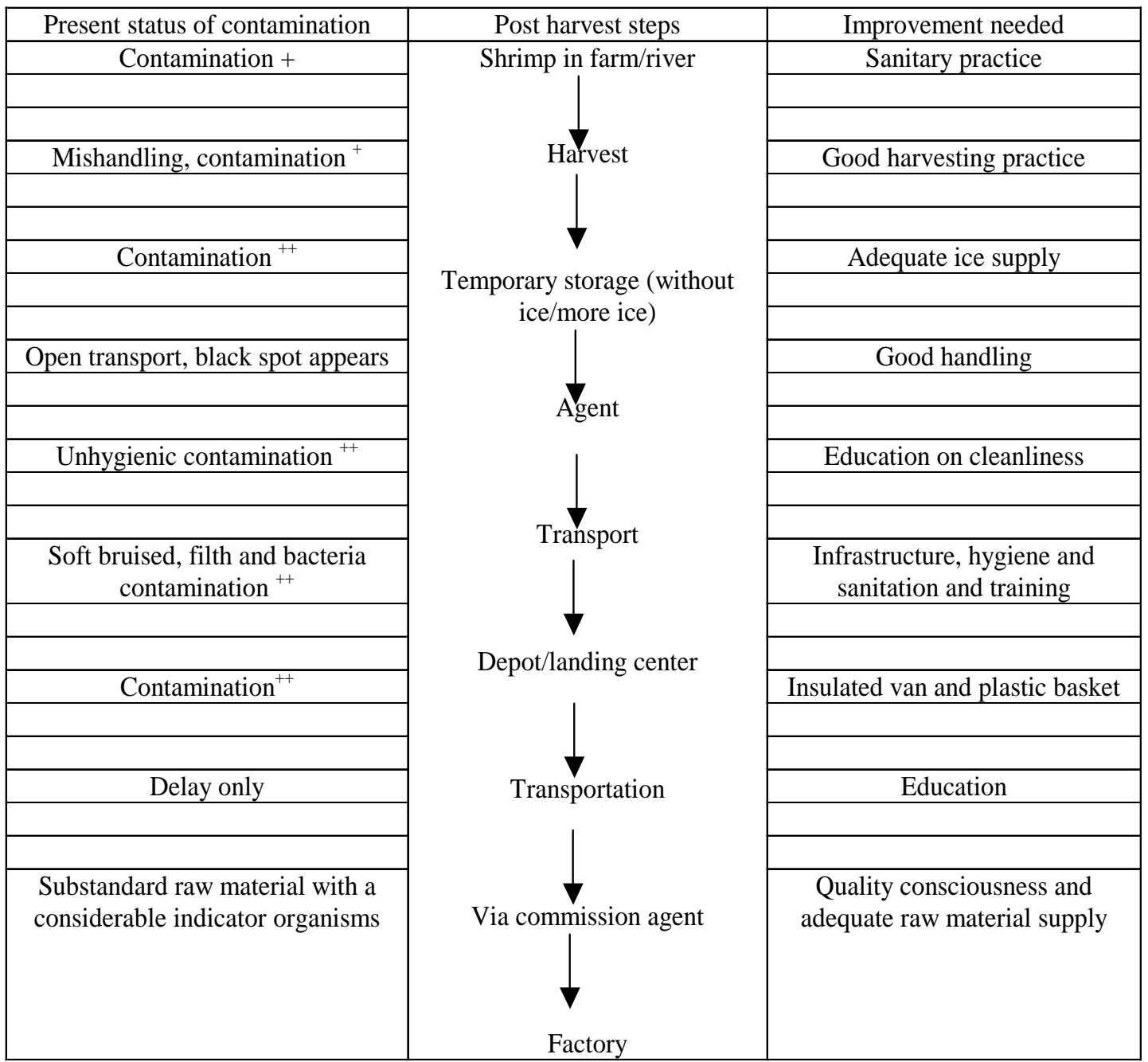

+= Critical Control Point (CCP)

Chart 1. Post-harvest flow chart of fish/prawns in the fish processing plants in Khulna 
iii) Contamination from every corner occurs while the raw materials remain at the landing centres.

iv) A HACCP system suggests to apply sorting measure of the raw materials by visual and odour test, and to maintain cleanliness at the centres. Chart 1 suggests the improvement needed in the post-harvest system of fishes to obtain hazard free products. Unfortunately, these measures are not thoroughly satisfactory at each of the Processing Plants.

C. Critical points at Processing Plants: The critical points identified at the Processing Plants have been presented in Chart 2. From the flow chart, it is revealed that there is every risk of contamination of the frozen products during processing. So, implementation of HACCP system and training of the Farmers Associates and workers of the plants must be obligatory to obtain better products. The visited plants maintained the HACCP system which can be described by the model of Chart 3.

However, after strictly following the HACCP principles, the end products may even show the presence of microbial load resulting in increased values of TMA (Trimethyl amino acid) and TVBN (Total Volatile Base Nitrogen) exceeding the critical limit of the product (Nargis et al. 2002). This may happen when the storage time of either ice or the product is longer, temperature and humidity of the plant during storage (Stansby 1963, Ahmed 2001).

The present investigation shows that in order to give quality assurance of frozen fish of Bangladesh, the application of HACCP system is needed from farm to consumption. Presence of middle-men in transporting of catch from farm to factory is the major critical point of hazard, resulting in time laps between harvesting and start of processing (Johnson and Clucas, 1990). Quality of raw materials on arrival at the factory should be verified, and the temperature of the plant should be treated as a hazard control point (Huss 1995). Types of ice has a profound effect on chilling and flaked ice are generally best to serve this purpose (Huss 1995) while the bacterial level in ice-fish was found to be higher in aerobic condition (Dalgaard et al., 1993). Huss (1994) suggested that identifying all hazards, defects and Critical Control Points (CCP), an appropriate monitoring and checking system can be established at each CCP in the freezing points. The plant facility, operational practices, process control, production planning of the Processing Plants (based on HACCP system) are more or less comparable to those of the developing countries; and the skill and capacity of the technical staffs are not inferior to any way (Ahmed, 2001). 




Chart 2. Flow chart showing processing of fish/prawns in fish processing plants at Khulna 


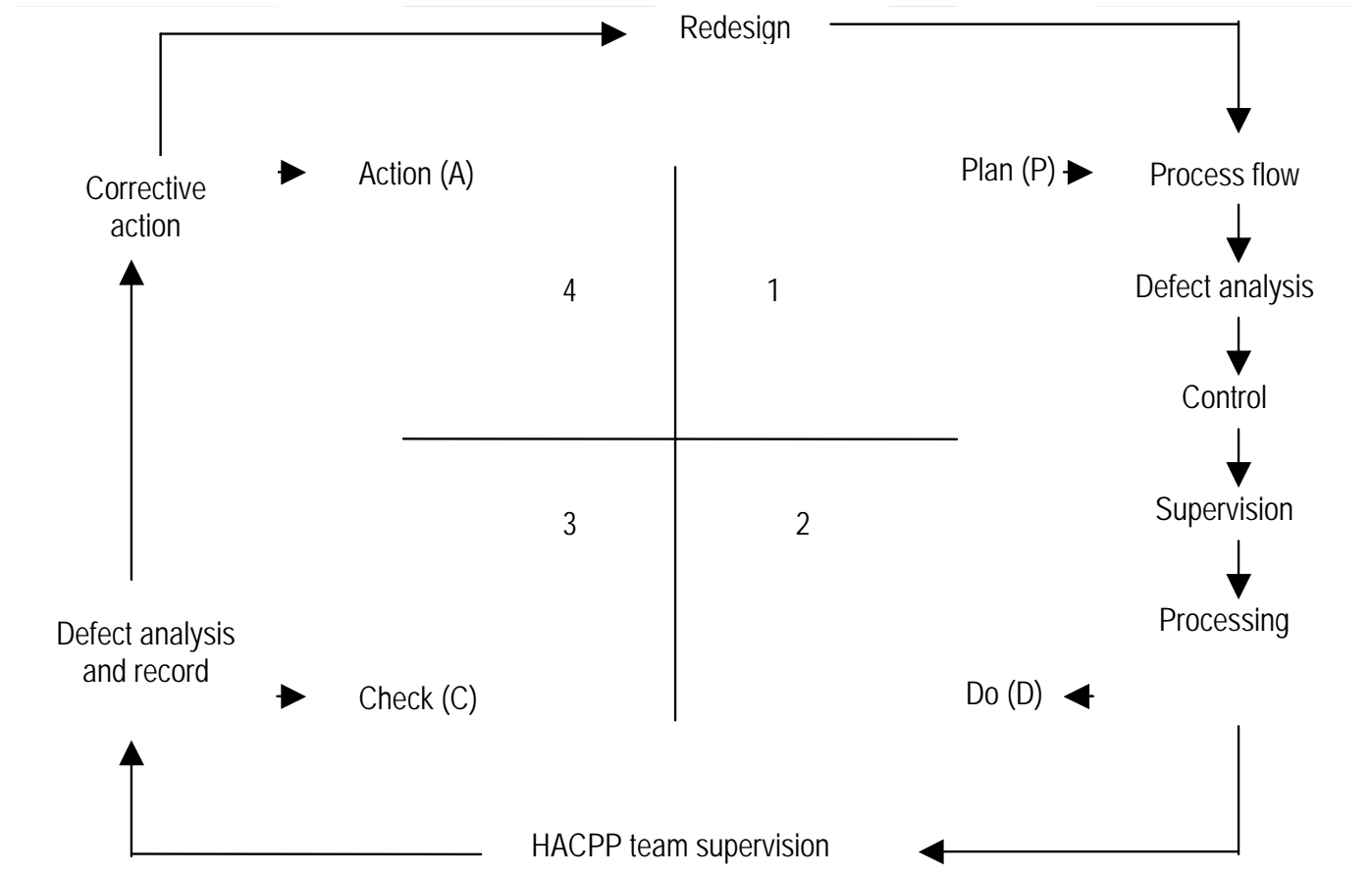

Chart 3. Design of a circular controlled production

\section{Conclusion}

The present study shows that there is every possibility of different high risk of contamination at phases from catch to processing systems. Water quality (both of farm and water used in ice making), harvesting methods and transportation of catch to the plants are the major risk areas for getting contamination-free catch.

\section{References}

Ahmed, M.K. (2001) Implementation of HACCP -A means of sustainable seafood export business. Bangladesh Sea Food 1: 17-23
Bhuiyan, M.D.H. (2004) Positive impact of HACCP in seafood quality. P. 14th Biennial National Conf. Zoological Soc. Bangladesh, Dhaka, 26-27 Feb. 2004. (Abstract No. 47), 30p.

Connell, J. J. (1971) Quality control in the Fish Industry. Torry advisory Note No. 58. Torry Research Station McapoAFF, p. 1-18.

Dalgaard, P. Gram, L. and Huss, H.H. (1993) Spoilage and self life of cod fillets packed in vacuum or modified atmosphere. Int. J. Food Microbiol. 19: 283-294. 
Huss, H.H. (1995) Quality and quality changes in fresh fish. FAO Fisheries Technical paper 348, Government of Denmark.

Huss, H.H. (1994) Assurance of seafood quality. FAO Fisheries Technical paper 334, p. 147.

Johnson, S.E. and Clucas, J.J. (1990) How to make fish boxes. Natural Resources Institute (UK), Technical leaflet No. 3
Nargis, A. Hossain, M.A. and Parween. S. (2002) Assesment of fish spoilage in HACCP implemented freezing plant of Bangladesh. J. bio-sci. 1-9

Stansby, M.E. (1963) Analytical Methods Industrial Fishery Technology. Reinhold publishing Corporation. p. 359-371.

Received : August 01, 2007;

Accepted : December 04, 2007 